bifurcations and bends and may be related to low velocity low shear areas forming. ${ }^{1+16}$ This might result in local accumulation of lipids and other constituents, and activated platelets and white cells might spend longer at the site, promoting their interaction with the endothelium. Smoking is associated with an increased packed cell volume, increased circulating fibrinogen concentrations, and blood viscosity ${ }^{17} 18$ and hence might encourage further blood stagnation in these areas. ${ }^{19}$ Thus a combination of smoking and haemodynamic factors might promote atherogenesis in specific sites of the arterial tree and perhaps more in peripheral than in coronary arteries.

Senior Lecturer in Epidemiology

F G R FOWKES

Department of Community Medicine,

Usher Institute,

Medical School,

Edinburgh EH8 9AG

1 Reid DD, Holland WW, Humerfelt S, Rose G. A cardiovascular survey of British postal workers. Lancet 1966;i:614-8.

2 Hughson WG, Mann JI, Garrod A. Intermittent claudication: prevalence and risk factors. Br.Med 7 $1978 ; i: 1379-81$
3 Widmer LK, Stahelin HB, Nissen C, da Silva A. Venen-, Arterien-Krankheiten, koronare Herzkrankheit bei Berufstätgen. Bern: Huber, 1981.

4 Reunanen A, Takkunen H, Aromaa A. Prevalence of intermittent claudication and its effect on mortality. Acta Med Scand 1982;211:249-56.

5 Schroll $M$, Munck $O$. Estimation of peripheral arteriosclerotic disease bv ankle blood pressure measurements in a population study of 60 year old men and women. $\mathcal{F}$ Chronic Dis 1981;34:261-9. 6 Dawber TR. The Framingham study. Cambridge, Massachuserts: Harvard University Press, 1980. Lord JW. Cigarette smoking and peripheral atherosclerotic occlusive disease. FAMA 1965;191: 249-51

8 Fowkes FGR. Epidemiology of atherosclerotic arterial disease in the lower limbs. European fournal of Vascular Surgery 1988;2:283-91

9 Kannel WB, McGhee DL. Update on some epidemiological features of intermittent claudication: The Framingham Study. I Am Geriatr Soc 1984;33:13-8

10 Da Silva A, Widmer LK, Ziegler HW, Nissen C, Schweizer W. The Basle longitudinal study: report on the relation of initial glucose level to baseline ECG abnormalities, peripheral artery disease, and subsequent mortality. I Chronic Dis 1979;32:797-803.

11 Meerloo JM, Billimoria JD. High density lipoprotein cholesterol levels in peripheral vascular disease and in women on oral contraception. Atherosclerosis 1979;33:267.

12 Bihari-Vargi M, Szekely J, Gruber E. Plasma high density lipoproteins in coronary, cerebral and peripheral vascular diseases. The influence of various risk factors. Atherosclerosis 1981;40:337-45.

13 Hulley SB, Rosenman RH, Bawol RD, Brand RJ. Epidemiology as a guide to clinical decisions: the association between triglyceride and coronary disease. $N$ Engl f Med 1980;302:1383-9.

association between triglyceride and coronary disease. $N$ Engl.
Woolf N. Pathology of atherosclerosis London: Butterworth, 1982.

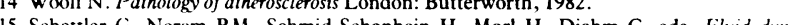
Schettler G, Nerem RM, Schmid-Schonbein H, Morl H, Diehm C, eds. Fluid dynamics as a localising factor for atherosclerosis. Berlin: Springer-Verlag, 1983.

16 Goldsmith HL, Karino T. Microrheology and clinical medicine; unravelling some problems related to thrombosis. Clinical Hemorheologv 1982;2:143-56.

17 Ernst E, Matrai A, Schmolzl C, Magyarosy I. Dose effect relationship between smoking and blood rheology. Br f Haematol 1987;65:485-7.

18 Meade TW, Imeson J, Stirling Y. Effects of changes in smoking and other characteristics on clotting factors and the risk of ischaemic heart disease. Lancet 1987;ii:986-8.

19 Lowe GDO. Blood rheology in general medicine and surgery. Clinical Haematology 1987;1:827-61.

\title{
Spending some of the preregistration year in general practice
}

\section{Needs incentives to make it happen}

"Why is it," asked one of my students, "that in hospital I hear so much that's bad about the hospital?" That student is not alone in raising such a question..$^{1-4}$ When one group is critical of another the criticism may be deserved; the critic may be mad, sad, or bad; or neither side may understand the other. Though there are undoubted faults in both hospitals and general practice, the main cause of strain lies in misunderstanding - whereas all doctors have worked in hospital only a few hospital doctors have experience of general practice.

For this reason the Medical Health Act of 1978 allowed the possibility that experience of general practice could be provided in the preregistration year. The splitting of the first year after qualification into three periods of four months with two periods spent in traditional medical and surgical rotations allows a preregistration doctor to be attached to a general practice. This experience should be valuable in bridging the gap in understanding between the two main branches of the health service. The same idea has been attracting attention in New Zealand, and a recent report from Australia recommends a mandatory two year preregistration term including general practice. ${ }^{5}$

But the opportunity to do general practice before registration is rarely taken. There are a few reports of preregistration doctors working in general practice,,$^{6.9}$ and all emphasise the legal, administrative, and academic difficulties in such a programme. Only a few general practices are suitable and willing to undertake such teaching, which, unlike teaching vocational trainees or students, carries no financial inducement. The recurring presence of an inexperienced doctor in a practice every four months is disruptive and presents organisational problems in prescribing and continuity of care. On the other side, young doctors may be reluctant to depart from the usual pattern of preregistration posts and to appear different when starting on a career already overpacked with "essential" experience. Against these negative aspects should be weighed the obvious enthusiasm reported by all those who have had experience of such a scheme; subsequently no harm has been done to a houseman's career, and the unusual experience has aroused great interest at interviews. ${ }^{6}$

Experience in general practice for the future specialist holds out the hope of bridging a schism which mars the health service. Yet little is done to encourage it, and the schemes that have been reported have struggled against considerable odds to achieve their success. New schemes are unlikely to develop unless rewards are offered to attract suitable applicants and general practices. Incentives for the practices might take the form of grants for special equipment as well as financial reward. It is less easy to see how young doctors might be encouraged to apply for preregistration posts in general practice, and a mandatory requirement as recommended in Australia is impossible for lack of suitable practices.

Senior Lecturer in Palliative Care,

F M HULL

Department of General Practice,

The Medical School, University of Birmingham,

Edgbaston, Birmingham B15 2TJ

\footnotetext{
1 Cartwright A, Anderson R. General practice revistled. London: Tavistock, 1981. Dowie R. General practitioners and consultems. London: Z7ing Edward's Hospital Fund, 1983. Hiatt HH. America's health in the halance New York: Harper and Row, 1987.

4 Hull FM, Westerman RF. Referral to medical outpatients departments at teaching hospitals in Birmingham and Amsterdam. Br Med $\mathcal{F}$ 1986;293:311-4.

Doherty RL, Amos BJ, Hicks N, et al. Report of the Committee of Enquiry into Medical Education and the Medical Workforce. Canberra: Australian Government Publishing Service, 1988.

6 Harris $\mathrm{CM}$, Dudley HAF, Jarman B, Kidner PH. Preregistration rotation including general practice St Mary's Hospital Medical School. Br Med J 1985;290:1811-3.

Harris CM. Pre-registration posts in general practice. Med Educ 1986;20:136-9.

8 Freeman GK, Coles CR. The preregistration houseman in general practice. Br. Med J 1982:284: 1379-83.

9 McGuinness BW. A house officer attachment in general practice. Practitioner 1982;226:1216-8.
} 